\title{
Purification of some active ingredients of alcoholic extract of anise seed (Pimpinella anisum) and assessment their estrogenic effect on some physiological traits of immature female mice
}

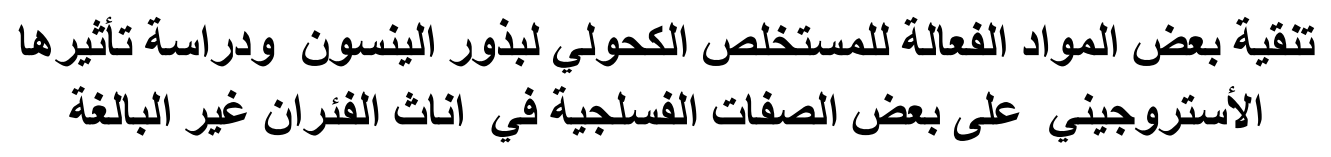

Anwar I. obead

kahtan A. Al-mzaein

Essam F. Al-jumaily*

College of veterinary medicine/Baghdad University

*Institute of genetic engineering And biotechnology for post graduate studies/ Baghdad University

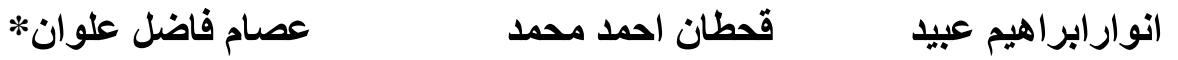

$$
\begin{aligned}
& \text { قسم الفسلجة و الأدوية /كلية الطب البيطري / جامعة بغداد }
\end{aligned}
$$

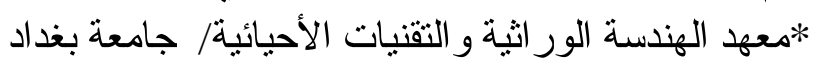

\begin{abstract}
This experiment was conducted in order to purify some active ingredients of $70 \%$ alcoholic extract of aniseed by adsorption chromatography on silica gel and gel filtration on sepharose CL-6B column, using phosphate buffer (0.1M, pH 7.0) as eluent, as well as gel filtration on sephadex LH-20 where chloroform : methanol (3:1) was used as an eluent. Thin layer chromatography on silica gel was used as a criterion for the identification of purified fractions. Ultra violet transilluminator as well as vanillin- $\mathrm{H}_{2} \mathrm{SO}_{4}$ reagent were used to identify and develop of separated fractions, respectively. However, the fractions which purified on sephadex LH-20, showed an $\mathrm{R} f$ value (0.71) which corresponded to the $\mathrm{R} f$ values of anethole. To assess the estrogenic activity of purified fractions a dose of $150 \mathrm{mg} / \mathrm{kg}$ of body weight of collected fractions were given to immature female mice at three weeks age and administered orally for four weeks period. Twenty immature female mice were divided randomly into five groups. First group received crude extract of aniseed, while the second, third, and fourth groups received fractions purified on silica gel, sepharose CL-6B and sephadex LH-20 columns, respectively. Group five served as control, such treatments were continued until maturity, and then the animals were sacrified for studying weight changes in ovaries and uterus. The results of this study revealed that there is a significant increment $(\mathbf{P}<0.01)$ in the weights of ovaries in the treated groups as compared to the control, while fractions obtained from sepharose CL-6B had no significant effect $(P>0.01)$. Also there is a significant increment $(P<0.01)$ in the weights of uterus in the treated group with respect to
\end{abstract}


fractions obtained from sephadex LH- 20 as compared to other treated groups and control.

استهدفت هذه التجربـة تتقية بعض المواد الفعالـة الموجودة في المستخلص الكحولي لبذور الينسون باستخدام

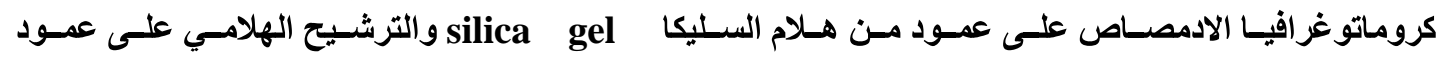
مس sepharose CL-6B باستخدام دارئ القوسفات بتركيز 0.1 مسولاري وبـأس هيدروجيني 7.0 لإسـترداد النماذج ، كما تم استخدام الترشيح الهلامي ايضا على عمود من Sephadex LH-20 واسترد النموذج باستخدام

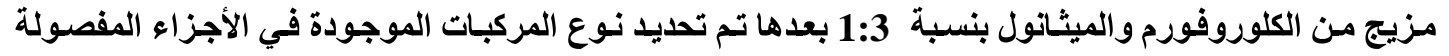

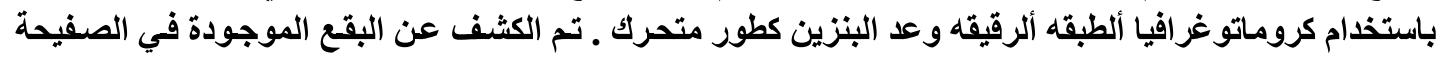
باستخدام الاشعه فوق البنفسية والكاشف (vanillin-H2 SO4) وحدوت ألبقعه في تراكيز الأجزاء المفصولة من

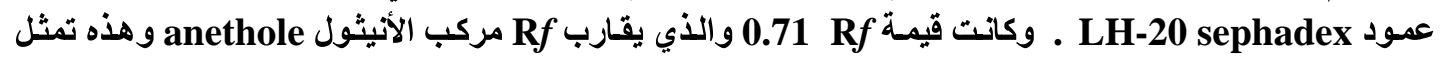
نسبة 90-80\% من مجموعة الزيوت الطيارة والتي تعد من أهم المواد الفعالـة الموجودة في بذور الينسون والتي

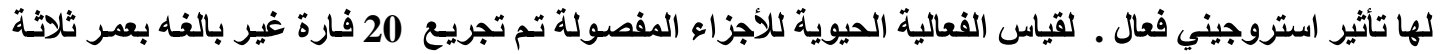

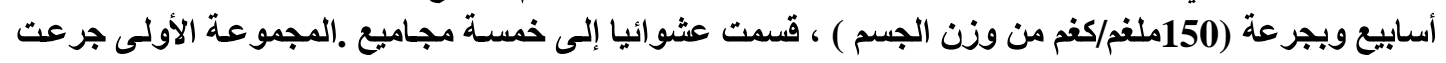

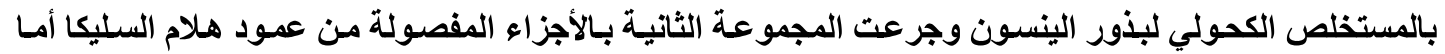
الثالثة فقد جرعت بالأجزاء المفصولة من عمود هلام sepharose CL-6B وجرعت المجمورعة الرابعة بـالأجزاء المفصولة من عمود sephadex LH-20 وعدت المجموعه الخامسة كمجموعة سيطرة واستمرت المعاملة لحين البلوغ الجنسي بعم سبعة أسابيع عند ذلك تم التضحية بها لاراسة التغيرات ألوزنيه في كل من المبايض والأرحام . أظهرث النتائج زيادة معنوية عالية (P.01)

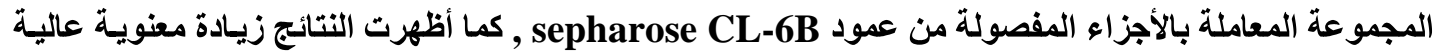
sephadex م>0.01)

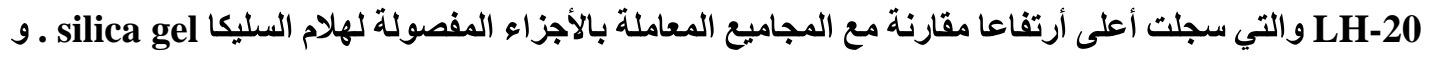
sepharose CL-6B

\section{Introduction}

Herbs have been used for nutritive and medicinal purposes for centuries. The World Health Organization estimated that $80 \%$ of the earth's inhabitants rely on traditional medicine for their primary health care needs, and most of this therapy involves the use of plant extracts or their active components [1]. Anise (Pimpinella anisum) is an annual herb indigenous to Iran, India, Turkey and many other warm regions in the world. Chemical analysis of anise oil showed the presence of the following active ingredients: anethole which represented (85\%) of the essential oil as well as eugenole methylchavicol, anisaldhyde and estragole. Moreover, anise was employed in folk medicine in many parts of the world for stimulating digestion and give antiparasitic [2], antibacterial [3, 4] antifungal [5] and antipyretic effects [6]. Additionally, the plant and especially its fruit has been used to cure a variety of diseases including seizures and epilepsy [7, 8]. Aniseed (Pimpinella anisum) is a plant, which has been used as estrogenic agents for millennia, specifically to increase milk secretion regulate menstruation, and facilitate birth [9]. The galactogoual role of crude extract of aniseed was proved by [10] when the crude alcoholic extract was administrated during the last trimester of pregnancy; on the other hand, [11] found that aniseed extract stimulates mammary gland growth when given at prepubertal time. Aniseed oil possess an estrogen and progesterone like action on the rat's mammary gland [12]. [13] concluded that the administration doses (43 mg, 86mg / kg B.W.) of anise oil to male mice resulted in amarked improvement in reproductive capacity, which 
explained by the effect of treatment on spermatogenesis, probably by hormonal regulation across hypothalamic-pituitary-testicular axis. However this experiment was aimed and designed to evaluate the estrogenic performance of the active ingredients of aniseed in albino immature female mice, by using chromatographic purification of bioactive componentes of alcoholic extract of aniseed on silica gel, sepharose CL-6B and sephadexLH-20, and identification of purified fractions.

\section{Materials and methods}

The experiment was take place at Institute of genetic engineering and biotechnology for post graduate of Baghdad University in January-August/2007, where seventy percent of alcoholic extract was prepared according to the procedure of [14]. Purification of $70 \%$ alcoholic extract of anis seed was carried out using column chromatography technique: -

1. Column chromatography on silica gel, a glass column of $(20 \times 2.2 \mathrm{~cm}$ I.d.) was prepared according to the [15]. Silica gel (270-300 mesh) 0.1M phosphate buffer pH, 7.0 was used as eluent .

2. Column chromatography on sepharose CL-6B gel, glass column of (56x1.5 cm I.d.) was prepared according to the directions of the supplied company (Pharmacia-Sweden) phosphate buffer $0.1 \mathrm{M}, \mathrm{pH} 7.0$ as eluent.

3. Column chromatography on sephadex LH- 20, glass column of (38x $1.6 \mathrm{~cm}$ I.d.) was prepared according to the directions of Pharmacia-Sweden Company. Amixture of chloroform: methanol at ratio of 3:1 was used as eluent.

4. Thin layer chromatography technique, silica gel type $G$ in the form of thin layer on aluminum plate supplied from Fluka Company benzene used as a mobile phase $[14,16]$. Five groups of a weanling female mice at 3 weeks age including four mice/group were divided randomly into:-

Group one: Animals in this group received orally $150 \mathrm{mg} / \mathrm{kg} \mathrm{B.W}$. of alcoholic extract of aniseed suspended in $50 \mu \mathrm{L} 0.01 \mathrm{M} \mathrm{pH} 7.0$ phosphate buffer [10].

Group two: received orally $150 \mathrm{mg} / \mathrm{kg} \mathrm{B.W}$. fractions of $70 \%$ alcoholic extract purified on silica gel column.

Group three: received $150 \mathrm{mg} / \mathrm{kg} \mathrm{B}$.W. fractions of $70 \%$ alcoholic extract purified on sepharose CL-6B column.

Group Four: received $150 \mathrm{mg} / \mathrm{kg}$ B.W. fractions of $70 \%$ alcoholic extract purified on sephadex LH-20 column.

Group five: Animals in this group served as control under similar conditions and administered orally $50 \mu \mathrm{L}$ of $0.01 \mathrm{M}, \mathrm{pH} 7.0$ phosphate buffer / animal daily. Parameters studied involved relative weights of ovary and uterus.

Statistical analysis: Completely randomized design (CRD) program [17] was used to test the effect of the treatments on traits involved in this study. The least significant difference (LSD) test was also used to compare significance between the means [18].

\section{Results}

The result of this experiment showed that chromatography of $70 \%$ alcoholic extract of anis seed on sephadex LH-20 column yield to some extent a homogenous symmetrical peak Figure (3). On the other hand neither silica gel nor sepharose CL-6B column yields 
pure fractions Figures $(1,2)$. Thin layer chromatography technique revealed that the bioactive fractions obtained from sephadex LH-20 column appears as rose color spot seen by using UV transilluminator and vanillin $-\mathrm{H}_{2} \mathrm{SO}_{4}$ reagent, which has $\mathrm{R} f$ value equal to 0.71 .This $\mathrm{R} f$ value identical to $\mathrm{R} f$ value of anethole reported by [14]. Furthermore, fractions yield from silica gel and sepharose CL-6B column had not given any spots on the TLC plate Figure (4). The results clearly showed Figures (1, 2, 3 ) that sephadex LH20 was a superior matrix for the fractionation of $70 \%$ alcoholic aniseed extract, and the symmetrical single peak was identified on TLC plates.

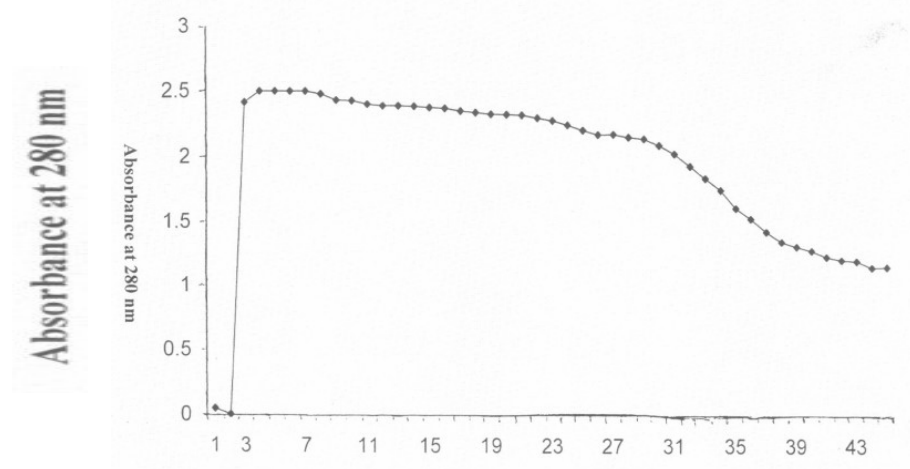

Fractions number

Fig (1): purification of $70 \%$ alcoholic extract of aniseed on silica gel column (20x2.2), phosphate buffer $0.1 \mathrm{M}$ at $\mathrm{pH} 7.0$ was used as an eluent at flow rate of $60 \mathrm{ml} / \mathrm{hr}$, fraction size $5 \mathrm{ml}$.

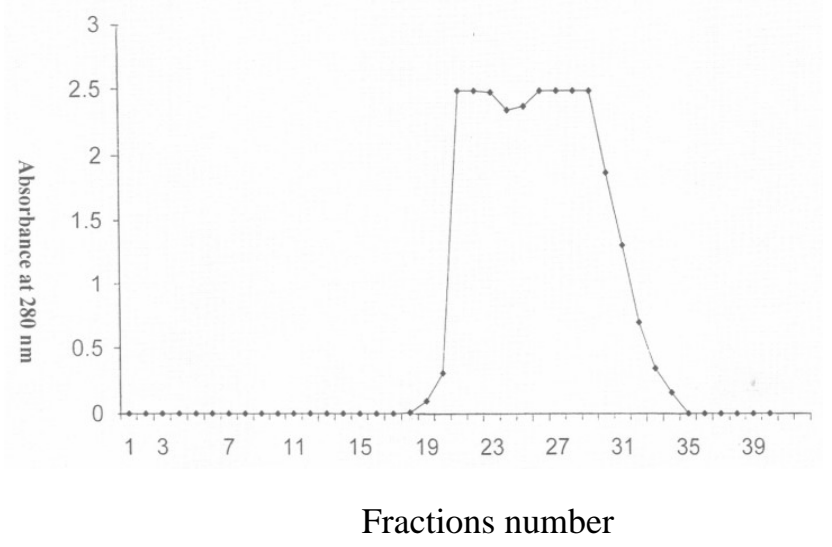

Fig (2 ) : purification of 70\% alcoholic extract aniseed of on sepharose CL-6B column $(56 \times 1.5 \mathrm{~cm})$ phosphate buffer $0.1 \mathrm{M}$ at $\mathrm{pH} 7.0$ was used as an eluent, at flow rate of $60 \mathrm{ml} / \mathrm{hr}$, fraction size $5 \mathrm{ml}$. 


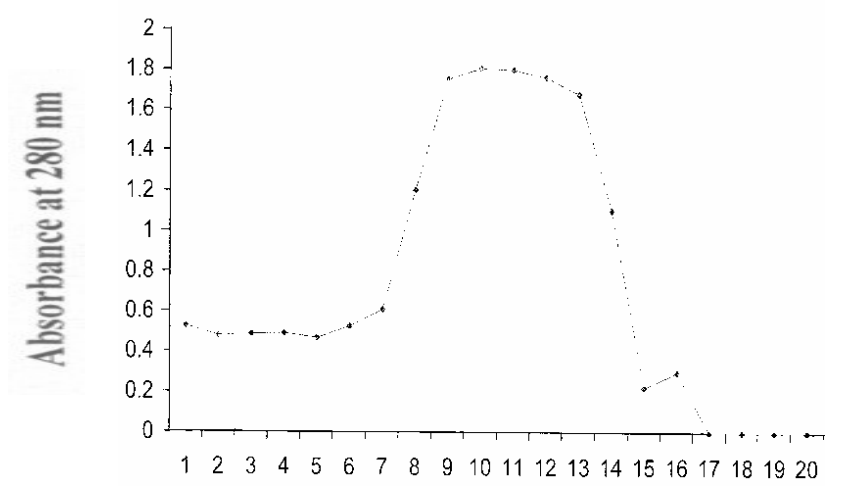

Fractions numbe

Fig (3): purification of alcoholic extract of aniseed on sephadex LH-20 column $(38 \times 1.6 \mathrm{~cm})$ chloroform:methanole $(3: 1)$ was used as an eluent at flow rate of $30 \mathrm{ml} / \mathrm{hr}$, fraction size $5 \mathrm{ml}$.

Fig (4): chromatogram TLC analysis using benzene as mobile phase and vanillin- $\mathrm{H}_{2} \mathrm{SO}_{4}$ for the development of the spots.

Number 1and 2 represent the fractions obtained from silica gel column.

Number 3 and 4 represent the fractions obtained from silica gel column and decolorized by charcoal.

Number 5 and 6 represent the fractions obtained from sephadex LH-20 column and decolorized by charcoal.

Number 7 represent the fractions obtained from sepharose CL-6B column and decolorized by charcoal.

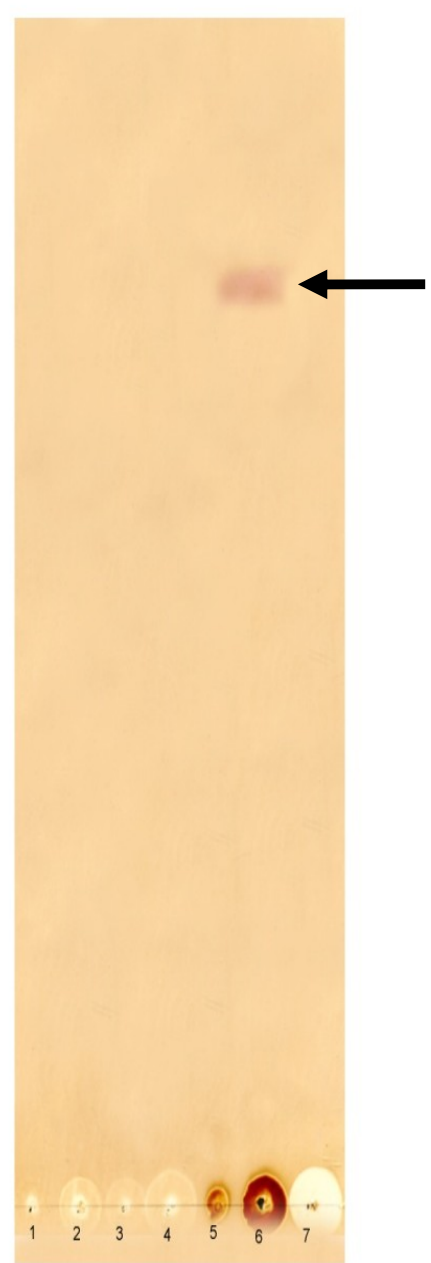


The results exhibited in table (1) revealed that there were no significant differences, $(\mathrm{P}>0.01)$ in ovaries weight $(\mathrm{gm} / 100 \mathrm{gm} \mathrm{B.W}$.) of immature female mice treated for 4 weeks with $150 \mathrm{mg} / \mathrm{kg} \mathrm{B.W}$. in fractions purified on sepharose CL-6B $(0.024 \pm 0.001)$ as compared to the control $(0.028 \pm 0.005)$. On the other hand, there was asignificant increment $(\mathrm{P}<0.01)$ in ovaries weight in groups of mature female mice treated with $70 \%$ alcoholic crude extract $(0.051 \pm 0.005)$. Fractions eluted by silica gel $(0.037 \pm 0.001)$ and sephadex LH-20 $(0.051 \pm 0.011)$ as compared to the control, respectively. The relative weight of uterus in immature female mice after 4 weeks of oral administration of $70 \%$ alcoholic crude extract of aniseed and fractions purified on adsorbent or gel filtration chromatography columns were showed in table (1). Fractions of $70 \%$ alcoholic aniseed crude extract purified on sephadex LH-20, chromatography column caused significant increment $(p<0.01)$ in the uterus weight of immature female mice $(0.617 \pm 0.135)$ as compared to the control group $(0.153 \pm 0.012)$. Furthermore, other groups of animals treated with crude extract and fractions eluted from silica gel and sepharose CL-6B columns recorded no significant increment $(\mathrm{P}>0.01)$ in the weight of the uterus which being $(0.287 \pm 0.097),(0.192 \pm 0.030)$ and $(0.225 \pm 0.029)$, respectively as compared to the control $(0.153 \pm 0.012)$.

Table (1): Effect of purified fractions of $70 \%$ alcoholic crude anis seed extract on ovaries and uterine weight $(\mathrm{gm} / 100 \mathrm{gm} \mathrm{B} . \mathrm{W}$.) of immature female mice at 3 weeks aging and treated for 4 weeks.

\begin{tabular}{|c|c|c|}
\hline \multirow{2}{*}{ Treatments } & Mean \pm SE \\
\cline { 2 - 3 } & Mean\% of ovary weight & Mean\% of uterus weight \\
\hline Control & $0.028 \pm 0.005^{\mathrm{b}}$ & $0.153 \pm 0.012^{\mathrm{b}}$ \\
\hline Crude Extract & $0.051 \pm 0.005^{\mathrm{a}}$ & $0.287 \pm 0.097^{\mathrm{b}}$ \\
\hline Silica gel & $0.037 \pm 0.001^{\mathrm{ab}}$ & $0.192 \pm 0.030^{\mathrm{b}}$ \\
\hline Sepharose CL-6B & $0.024 \pm 0.001^{\mathrm{b}}$ & $0.225 \pm 0.029^{\mathrm{b}}$ \\
\hline Sephadex LH-20 & $0.051 \pm 0.011^{\mathrm{a}}$ & $0.617 \pm 0.135^{\mathrm{a}}$ \\
\hline LSD & 0.0188 & 0.2326 \\
& $* *$ & $* *$ \\
\hline$*$ p $<\mathbf{0 . 0 1}$ & &
\end{tabular}

Values are expressed as the Mean $\pm \mathrm{SE}, \mathrm{n}=5$ /group

Mean in the same column with no common superscript differ significantly $(\mathbf{p}<0.01)$.

\section{Discussion}

Sephadex LH -20 is lipophilic cross-linked dextran derivative, used for the fractionation of organic- soluble natural products such as steroid, fatty acids, and porphyrin and carotenoid pigments. $[19,20]$. Anethole was eluted as a symmetrical peak on sephadex LH-20 conferming the sutability of this matrix for the superior separation rather than silica gel and sepharose CL-6B.

TLC was used in this work to detect anethole extracted from aniseed. The $\mathrm{R} f$ value was approximately the same as recorded by [14] which was 0.71 using benzene as mobile phase, while $\mathrm{R} f$ recorded by [16] was 0.69 using the anethole same mobile phase, on other hand [21] reported that the $\mathrm{R} f$ value of anethole was 0.74 using chloroform /ethyl-acetate / 
formic acid (85:15:1) as mobile phase. It is important to mention that the normal range for $\mathrm{R} f$ value of anethole is between 0.69-0.74.

Anethole is the most active ingredients of aniseed and represented $85 \%$ of essential oil, and the estrogenic potency was attributed to the polymer forms of anethole (dianethole, photoanethole), this estrogenic activity was discussed on the bases of the structural similarity of anethole and dopamine. Dopamine acts to inhibit the secretion of prolactin, but that effect could be repressed by successful competition of anethole at the appropriate receptor sites [9].

The results of this experiment Table (1) indicated that fractions of $70 \%$ alcoholic purified aniseed extract on sephadex LH- 20 column which contains mainly anethole exert an estrogenic effect in immature female mice reproductive system through some remarkable observations such as weight increment of the ovaries and uterus. Growth and maturation of ovaries under the control of gonadotropic hormones (FSH and LH) secreted from pituitary gland during sexual puberty. FSH stimulates cells of ovarian follicles to synthesize estrogen, and stimulates the development and growth of the primary follicles to secondary follicles and then to graafian follicles [22]. LH is responsible for induction of ovulation and formation of corpus luteum which stimulated to secrete progesterone. [23, 22].

The ovarian hormones play an important role in uterine weight increment through estrogen hormone activity which stimulates protein synthesis in the myometrium and increases divisions of endometrial cells. Progesterone increase growth and divisions of active uterine glands, and increase blood supply to the endometrium, all these changes will lead to increase of uterine weight. [24, 25]. Ovarian and uterine weight increment in prepubertal animals considered as one of the criteria that can be used in the bioassay of these hormones [26, 27]. However, the ovarian weight increment in this study may be attributed to the stimulatory effects of the anethole on granulosa cells of the ovarian follicles inducing their numbers and growth development, as well as accelerating maturation processes at different follicular stages, in addition to increasing blood supply and metabolic rates[22] .

However, the significant increment in the weight of the uterus may be attributed to the direct effect of anethole on cell division and proliferation induction of the uterine cells. On the other hand, the crude extract of aniseed showed a significant increment in the weight of ovaries of immature female mice. Similar results concerning to the effect of $70 \%$ alcoholic aniseed crude extract on the weight of ovaries and uterus of immature female rats was reported by [11]. Moreover, the estrogenic potency of anethole recorded in this experminet was confirmed histologicaly through an increament of endometrium layer thickness of uterus. [2]. 


\section{References}

1. William, S.P. and Losa, R. (2001). The use of essential oil and their compounds in poultry nutrition. World Poultry -Elsevier's, 17:14-15.

2. Cabuk, M.; Alcicek, A.; Bozkurt, M.; and Imer, N. (2003). Antimicrobial properties of the essential oils isolated from aromatic plants and using possibility as alternative feed additives .II. National Animal Nutrition Congress. 18-20 September, PP: 184-187.

3. Singh, G.; Kapoor, I. P.; Pandey, S. K.; Singh, U. K. and Singh, R. K. (2002). Studies on essential oil: part 1o; antibacterial activity of volatile oils of some spices. Phytother Res., 16:680-2.

4. Tabanca, N. E. ;Bedir, N. ;Kirimer, K. H.; Baser, S .L.; Khan, N .R . Jacob and Khan, J. A. (2003). Antimicrobial compounds from pimpinella species growing in Turkey.Planta Med. 69:933-938.

5. Soliman, K. M. and Badea,R. I. (2002). Effect of extracted from some medicinal plant on different Mycotoxigenic-Fungi.Food Chem.Toxicol.40:1669-1675.

6. Afifi, N.A.; Ramadan,A.; EL-Kashoury, E.A.; and El Banna, H.A. (1994). Some pharmacological activities of essential oils of certain umbeliferous fruits.Vet.Med.J.Giza, 42:85-92.

7. Abdul-Ghani, A.S.; El-Lati,A.I. ; Sacaan and Suleiman, M.S (1987). Anticonvulsant effects of some arab medicinal plants. International J.Crude Drug Res., 25: 39-43.

8. Avicenna,A.(1988).Drugs and decoctions used in epilepsy. In: Sharafkandi,A.(Translator), Ghanoon Dar Teb . Soroosh Press, Tehran, pp: 456-459.

9. Albert,M.P.(1980).Fennel and anise as estrogenic agents .Ethnopharmaclogical J. 2 (4) :337-440 .

10. Al-Saadi, J.A. (1997). Effect of Pimpinella anisum Extract on Mammary Gland Growth and development in Rats. PhD thesis, College of Veterinary Medicine, University of Baghdad.

11. Al-Jubori, A. R. (1999). Effect of Pimpinella anisum Extract on Prepubertal Mammary Gland Growth in Rats and Some Effects in Ovaries and Uteri. M.S.C. Thesis, Collge of Veterinary Medicine, University of Baghdad.

12. Esmail, M. M. (2005). Role of Aniseed (Pimpinella anisum) Oil on Mammary Gland Performance in Rats. PhD thesis, College of Veterinary Medicine. University of Baghdad.

13. Mustafa, S. M. (2006). Effect of aniseeds (pimpinella anisum) Oil on Male Reproductive System in mice. M.Sc thesis, Collage of Veterinary Medicine, University of Baghdad.

14. Harborne, J. B.(1984). Method of Extraction and Isolation, Phytochemical Methods, $2^{\text {nd }}$ edition, London New York champanand Hall.

15. Dalli, Basel Kamel,and Al-Hikeem, Saadik Hussan (1987).Food Analysis, Book House Printing, Baghdad University.

16. Stahl, E. (1969). TLC of Steroids and related compounds In: Thin layer Chromatography Hand book, $2^{\text {nd }}$ ed. Springer-Verlag, Berlin, Heidelberg, New York.

17. SAS, (2001). SAS/ STAT Users.Guide for personal computers. Release 6.12. SAS Institute Inc.,Cary,Nc.,USA(SAS=statistical analysis system). 
18. Steel, R.G.D. and Torrie, J. H. (1980).Principles and Procedures of Statistics, McGraw- H. 11 Book Company Inc.,

19. Unger, K. K. (1990).Packings and stationary phases in Chromatographic Techniques, in Chromatographic Science.series,vol.47,Dekker,New York.

20. Marston, A. and Hostettmann, K. (1991).Nat.Prod.Rep. 8,391-414.

21. Eyal, S.; Timor, B.; Uzi, R.; and Yuval, S. (2002). The trans- anethole degradation pathway in an Arthrobacter sp. J. Biol-chem., vol .277, Issue 14, 11866-11872.

22. Ganong, W. F. (2005). Review of medical physiology. $22^{\text {nd }}$ edition. Large medical Book /Mc Graw-Hill Boston, Toronto, New Jersey, PP: 424-340.

23. Elaine, N. Marieb (2005).Anatomy and Physiology $2^{\text {nd }}$ ed. Anatomy of the female reproductive system 921-937. San Francisco.

24. Schreiner, W. E. (1974). The ovary In: Clinical Endocrinology. Edited by: Labhart, A. Springer-Verlag, New York . pp:511-643

25. Guyton, A.C. and Hall, J. E.(2006). Textbook of Medical Physiology.Elsevier Inc. Philadelphia,Pennsylvania.

26. Al-A'araji, S.M. (1996). Extraction and Evaluation of urinary Human Menopausal Gonadotropin. M.Sc. thesis, College of Veterinary Medicine, University of Baghdad.

27. Al-Assady. J.K. (1998).Biological Assay of Extracted Gonadotropin From Urine of Ovariectomized Ewes. Ph D thesis,College of Veterinary Medicine, University of Baghdad.

28. Al-abdally, A. I. (2008). Purification of some active ingredients of alcoholic extract of aniseed (pimpinella anisum) and studying some of their physiological effects on the Female Reproductive system of mice. MSc thesis, College of Veterinary Medicine, University of Baghdad. 